\title{
Las ideas nacionalistas en Chile
}

Nationalist ideas in Chile

Moshe Nes El

nesel@netvision.net.il

Universidad Hebrea de Jerusalem

Israel

\section{Resumen}

El presente artículo, como su nombre lo indica, trata de las ideas nacionalistas en Chile, brinda un contexto histórico de los diferentes periodos presidenciales y la aparición de movimientos nacionalistas en el país desde el nacimiento del Movimiento Nacional Socialista hasta nuestros días.

Palabras Claves: Von Marées - Antisemitismo - Nacis - Nacionalista

\begin{abstract}
This article is about the nationalist ideas in Chile, it provides a historical context of the various presidencies and the emergence of nationalist movements in the country since the birth of the National Socialist Movement to the present day.

Keywords: Von Marées - Antisemitism - Nacis - Nationalist

Chile vivió un período tranquilo, desde 1830 a 1891. Entre 1810 a 1830 gobernaron los liberales (denominados en Chile "pipiolos"). Este período liberal, se caracterizó por una etapa anárquica de la historia del país. Desde 1830, toman el poder los "pelucones" (es decir, los conservadores). El eje y alma del comienzo de este período fue el Ministro Diego Portales, quien sin presentarse como candidato a la presidencia, controló toda la acción ministerial de su época.
\end{abstract}

El período de los conservadores se caracterizó por un gobierno impersonal, dirigido por un presidente, cuyo período duró 10 años, teniendo la mayor parte de la autoridad en el país. Según el escritor Edwards Vives, el gobierno conservador era como una continuación del régimen monárquico español, en el que el 
presidente tenía las atribuciones que antes de la Independencia, tenía el soberano. El poder efectivo pertenecía a la aristocracia del país.

El hecho de que el rey, y luego el presidente, estuvieran alejados en cierta manera del gobierno directo, permitía a grupos de la elite, gobernar con tranquilidad ${ }^{1}$.

La guerra contra los araucanos, tuvo gran importancia en el desarrollo de la vida política chilena. Durante todo el período hasta 1880, Chile desarrolló una importante acción militar contra los araucanos. Eso significó que la ciudad de Concepción, cercana a la frontera araucana, se transformara en un bastión militar y también político.

La figura de Diego Portales, tuvo y tiene una gran influencia, en el desarrollo de las ideas políticas de Chile. Hombre modesto, no aceptó honores, y trabajó con gran habilidad y esfuerzo para terminar con la anarquía de los años anteriores. Una revuelta militar logró capturarlo y ejecutarlo, creando así la leyenda de Portales, leyenda que simbolizaba el ideal de un gobierno autoritario.

En 1860, debido a problemas religiosos, se divide el Partido Conservador, y desde ese momento comenzó lo que en Chile se llama la República Liberal. Este fue un período de gran prosperidad. Chile venció en la Guerra del Pacífico a Perú y Bolivia, y anexó enormes territorios, ricos en minerales, que lo enriquecieron.

Paralelamente a esto, se originó una gran rebelión araucana en 1880, lo que permitió al gobierno enviar destacamentos completos desde el Perú y Bolivia, y definitivamente destruir el poderío araucano, creando importantes poblaciones en la región ${ }^{2}$.

En 1891 se declaró una guerra civil, un conflicto entre el presidente Balmaceda y el Parlamento. Balmaceda quería continuar el gobierno autoritario que tenían los presidentes, el congreso por su parte 
quería tomar el control del poder efectivo. La Guerra Civil terminó con la derrota y el suicidio del Presidente Balmaceda, y el comienzo de la República parlamentaria.

La figura del presidente Balmaceda está íntimamente ligada a la labor de un capitalista inglés de nombre North, quien logró una enorme fortuna en la Bolsa de Londres, usando las provechosas ganancias, que había conseguido por medio de las minas de salitre y cobre, y los ferrocarriles particulares que creó.

Así como la figura de Portales, quedó grabada como la leyenda del hombre fuerte que salvó a Chile, Balmaceda quedó ligado en el recuerdo del pueblo, como el promotor del drama que le costó la vida, cuando detrás de sus enemigos, se encontraba el capitalista ingles North. La intervención económica inglesa, que dominaba las salitreras, las minas de cobre y de bórax, los ferrocarriles, y el control parcial de la navegación marítima, fue realizada con completo desprecio del elemento nacional chileno, los ingleses dirigían la administración, y el peón chileno trabajaba ganando a duras penas el pan, en un trabajo de condiciones inhumanas.

El desprecio hacia el hombre del pueblo, hizo que algunos escritores defendieran al trabajador humilde, el mas famoso fue el Dr. Nicolás Palacios, cuyo libro, "La Raza Chilena", no solo defendió al "roto" chileno (como se llamaba al hombre del pueblo), sino que concibió una teoría, en la que se aseguraba, que el hombre del pueblo chileno, era un hombre fuerte, trabajador, como buen soldado, y que en realidad él era el producto del cruce entre el macho godo, y la madre araucana ${ }^{3}$.

La situación del pueblo chileno, luego de la Guerra del Pacífico, se transformó en dramática. Impulsados por las posibles ganancias que pudieran tener en las salitreras en el norte del país, numerosos campesinos chilenos abandonaron el sur del país, donde vivían en condiciones miserables de una semiesclavitud, y se dirigieron a las nuevas zonas conquistadas por Chile en el norte. 
Como ya hemos escrito, los dueños extranjeros, principalmente ingleses, de las salitreras, dieron a los chilenos condiciones inhumanas de vivienda, y de sueldo, para un trabajo físico de una jornada de 12 horas.

Después de la Guerra del Pacífico, el gobierno chileno se vio en la obligación, de cubrir los gastos y deudas que se habían generado en el conflicto bélico, para ello, usó una política inflacionista, abandonando el patrón del oro, y fijando el valor forzoso de la moneda.

Como resultado de esta política económica, se beneficiaron grandemente los latifundistas, pues ellos vendían sus productos en Europa, en valor de libras esterlinas, y pagaban a sus trabajadores, en valor del peso desvalorizado. O sea, el hombre simple del pueblo, recibía un sueldo en pesos, pero sus productos debía comprarlos en el valor de la libra esterlina, y por ello, le resultaba casi imposible sobrevivir.

A estos problemas se sumó el de los campesinos que se establecieron en las ciudades. Este éxodo aumentó la miseria del pueblo, y en las ciudades se crearon conventillos y chozas, siendo estos lugares foco de la delincuencia y la corrupción.

La clase acomodada despreciaba al "roto", al trabajador chileno. Según ellos, el chileno del pueblo, era un ser corrupto y flojo, adicto a la bebida, y por ello, preferían al trabajador europeo, que como inmigrante Ilegaría a Chile, y mejoraría las condiciones de vida del elemento autóctono, enseñándoles la virtud del trabajo, y la moderación en la bebida ${ }^{4}$.

Esta opinión sobre el trabajador chileno, no era compartida por empresarios argentinos, ingleses o norteamericanos, que consideraban que el obrero chileno era superior al local. Por ello fueron contratados miles de obreros chilenos, para construir los ferrocarriles en el Perú, o para las labores 
agrícolas en la Argentina. De tal modo, que se crearon núcleos de chilenos en esos dos países, que generalmente tropezaban con un fuerte espíritu antichileno ${ }^{5}$.

Esta situación se originó principalmente, debido al conflicto limítrofe con Argentina, y la amargura del pueblo peruano, por su derrota en la Guerra del Pacífico.

La angustiosa situación del obrero chileno y su progreso en la Argentina, originó un clamor público en Chile, y la exigencia de dar trabajo a los mismos en su país.

Al comienzo del siglo XX, la situación se agravó. El precio del salitre en Europa bajó considerablemente, y esto produjo el cierre de minas salitreras con el consiguiente despido de obreros y empleados chilenos, de tal manera, que la situación para éstos se hizo insostenible en la zona norte.

La situación difícil del obrero chileno provocó una serie de huelgas, y la creación de los primeros núcleos socialistas en el país. Muchos de ellos organizados por inmigrantes de esas ideas, llegados a Chile.

En 1907 la situación se tornó tan difícil, que miles de obreros y sus familias abandonaron las salitreras, y se establecieron en el puerto de lquique, puerto de donde salían los barcos con salitre a Europa, y se apoderaron de un colegio, en el que se establecieron. El resultado fue una violenta represión por parte del ejército, quienes masacraron a cientos de obreros y sus familias, incluso niños y mujeres. Este episodio provocó un cambio en el sector obrero. Ya en 1886 se creó el Partido Demócrata, que tenía como programa defender al obrero chileno, prohibir la inmigración (que quitaba trabajo a los nacionales) y dar tierras a los campesinos chilenos que carecían de ellas.

La agitación obrera provocó la reacción de las clases acomodadas y del gobierno, que ellas controlaban. Por ello, desde 1908, el gobierno comenzó a frenar la inmigración europea organizada, y en 1918 se dictó la ley de extranjería, que daba al gobierno la facultad de expulsar del país a todo extranjero que 
realizara actividades anarquistas, comunistas o socialistas. El primer expulsado fue un tal Natan Cohen, del que casi no tenemos mas noticias. El fin de la Primera Guerra Mundial trajo consecuencias económicas importantes para el país. La creación del Canal de Panamá provocó el comercio marítimo por ese canal, y por consiguiente el cese de gran parte del movimiento, lo que perjudicó el desarrollo del puerto de Valparaíso, y del comercio internacional entre Chile y el Lejano Oriente.

Durante la Primera Guerra Mundial, los alemanes que necesitaban urgentemente el salitre para la producción de bombas, se encontraron con la dificultad de traer ese material de Chile, por ello los alemanes realizaron experimentos químicos que llevaron como resultado la creación del salitre sintético. Después de la guerra ya no necesitaban comprar salitre en Chile, y por ello quedaron grandes cantidades de ese mineral, que no podían venderse, y nuevamente se cerraron numerosas plantas de extracción del salitre.

En Chile se formaron dos alianzas partidarias, una pertenecía a las clases dominantes, y la otra a los que pedían cambios en la política del gobierno.

En 1915 se realizaron elecciones parlamentarias en la provincia de Tarapacá. Frente al senador que dominaba la vida política de esa región, se presentó como candidato de la oposición un joven abogado, hijo de inmigrantes italianos, Arturo Alessandri. La campaña fue muy agitada y dura, y terminó con el triunfo de Alessandri, que tuvo un incidente con la policía local, en la que mató a dos de sus oponentes. El triunfo de Alessandri fue aclamado por las clases obreras y burguesas, quienes le dieron el apodo de "el león de Tarapacá", título que llevaría hasta la muerte ${ }^{6}$.

En 1920 se realizaron las elecciones presidenciales, la clase dominante presentó la candidatura de Luis Barros Borgoño, hombre ilustre y político hábil. En cambio, la combinación liberal, presentó la candidatura de Arturo Alessandri. La campaña fue muy reñida, y el resultado fue un casi empate entre los dos candidatos. Esta situación llevó a un estado tan tenso, que se pensaba en una guerra civil, sin embargo 
se logró un acuerdo, creándose un Tribunal de Honor, para dirimir las diferencias, ese tribunal, por una estrechísima mayoría, le otorgó el triunfo a Alessandri.

Alessandri tenía un programa amplio y bien intencionado, pero se encontró con la obstrucción del Parlamento, donde tenían mayoría sus detractores, y en esa forma impedían todo cambio.

Al Parlamento llegaron varios proyectos de Alessandri, para aumentar los sueldos al ejército, que vivía con sueldos muy bajos. El Parlamento rechazó ese pedido, y en cambio anunció el aumento de los sueldos de los parlamentarios. A esto reaccionaron los jóvenes oficiales, y se dirigieron el día de la sesión, al Congreso. Contraviniendo las leyes, rehusaron entregar sus sables, y al llegar la discusión en la que se rechazaba el proyecto de aumento de sueldos a los oficiales del ejército, y se aprobaba el aumento de los parlamentarios, los oficiales, que estaban en la tribuna de las visitas, comenzaron a hacer ruidos con sus sables, lo que era una declaración abierta de rebelión. Los suboficiales, se dirigieron al Club Militar, y declararon estar en sesión permanente.

Alessandri solidarizó con los militares, y estos enviaron una delegación de tres tenientes para coordinar con él las medidas a adoptar. Entre los 3 tenientes, había un judío, Isidoro Pimstein.

El Parlamento aprobó en pocas horas los proyectos que descansaban años en el mismo. El Presidente declaró que haría promulgar una nueva Constitución, pero un golpe militar, dirigido por el General Luis Altamirano, se apoderó del poder, y Alessandri salió al exilio, el que duró pocos meses, pues hubo una revolución civilista, que le pidió que regresara nuevamente a Chile. El regreso de Alessandri fue una verdadera apoteosis, y pudo fácilmente promulgar la Constitución de 1925. Esta Constitución puso término al régimen parlamentario, y se volvió al régimen presidencial.

Una nueva crisis ministerial se presentó cuando el Ministro de Defensa, Carlos Ibáñez del Campo, presentó su candidatura para las elecciones presidenciales que debían realizarse. Alessandri y los 
ministros creyeron que debería renunciar a su puesto ministerial, pero el rehusó a hacerlo. Para obligarlo, renunció todo el ministerio, pensando que así renunciaría, pero el General Ibáñez, no solo no renunció, sino que anunció, que desde ese momento, todos los decretos deberían ser firmados solo por el presidente y él, como único ministro no renunciante. Alessandri, que estaba a punto de terminar su período, salió al exilio, y el General Ibáñez empezó su dictadura, primero maniobrando para colocar en la presidencia a personas débiles de popularidad, y luego de varias peripecias políticas, asumió directamente la dictadura, en 1927, la que duró hasta 1931. En ese período se produjo la gran crisis económica de 1929, la que afectó profundamente la economía de Chile. Esta situación provocó una revolución estudiantil, que obligó a lbáñez a renunciar, y salir al exilio. Se originó nuevamente un período anárquico, en el que se sucedieron elementos políticos diferentes, incluso la creación de una República Socialista en 1932, que duró solo 100 días.

\section{La emergencia del Movimiento Nacional Socialista en Chile}

El desorden y la anarquía en Chile era parecida a la situación en Europa, donde luego de la anarquía producida al final de la Primera Guerra Mundial, surgieron regímenes militares y dictatoriales. En Chile surgieron en la opinión pública del país, voces que pedían seguir el ejemplo europeo.

En 1923, el prestigioso diario El Mercurio, publicó una editorial, donde se sugiere que Chile siga el ejemplo de los regímenes totalitarios. Otro prestigioso diario, Las Ultimas Noticias, publicó también una editorial semejante. ${ }^{7}$ Esas editoriales elogiaban el triunfo de Musolini en Italia.

Los fundadores del Movimiento Nacional Socialista en Chile, fueron intelectuales que habían estudiado en Alemania, como el economista Carlos Keller y el abogado González Von Marées, militares que habían desempeñado misiones en Alemania o Italia, como el general Fracisco J. Díaz ${ }^{8}$.

La ideología del nuevo movimiento se asemejaba mas a los regímenes fascistas, y su nombre era el que usaba el partido nazi en Alemania. 
Su ideología sostenía que la solución a los problemas de Chile, era la creación de un estado centralizado, bajo un liderazgo que diera tranquilidad al país y que organizara un régimen armónico y de trabajo.

La filosofía de ese partido correspondía a la de Nicolás Palacios, en su libro "Raza Chilena", que sostenía que en Chile se había originado una nueva raza, producto del desarrollo del país. Siendo Chile una de las más pobres colonias de España, llegaron españoles, en general guerreros, que buscaban glorificarse en las campañas contra los indios araucanos. Por su parte, los araucanos demostraron tener un gran valor, y pese a los esfuerzos, los españoles fracasaron en intentar dominarlos. Ese largo contacto provocó el mestizaje entre el guerrero español, y la mujer araucana, conjunto de una pareja de guerreros de gran valor, y con las mejores condiciones para desarrollar una raza especial, la raza chilena, que el Movimiento Nacional Socialista quería promover.

El movimiento chileno adoptó escribir la palabra nazi como naci, para diferenciarse del partido nazi alemán, este planteamiento originó la creación de otro partido nazista organizado por los alemanes residentes en Chile, y que aceptaban las premisas que llegaban desde Alemania. Su jefe era Rudolph Schwartzenberg. En 1935 el Movimiento Nacional Socialista de Chile expulsó al elemento alemán ${ }^{9}$.

Interesante es consignar la posición de los nacis chilenos en relación a los judíos. Podemos resaltar dos épocas, la anterior a 1940, y la posterior hasta la extinción del movimiento. En la primera fase el partido declara que solo se opone a los judíos que no se asimilen al país, pero acepta a aquellos que se integran totalmente al mismo. En el periódico "Trabajo", órgano del partido, se informa el caso de judíos miembros del partido, y de aquellos que se les considera como chilenos dignos de ser miembros del movimiento. El líder del partido naci Gonzalez Von Marées declaró en una entrevista a un periódico judío norteamericano, que el era descendiente de una abuela judía. Esa declaración provocó reacciones en su propio partido, lo que tuvo que corregir declarando que su bisabuela era judía, y no su abuela, y en esa forma podía incluirse en la raza aria según las leyes de Nüremberg. 
La segunda parte fue influenciada por los triunfos del nazismo, y el problema de los refugiados judíos que llegaron a Chile entre 1937 y $1940^{10}$. En este período el Movimiento Nacional Socialista, adoptó una posición más antisemita.

El movimiento naci en Chile creció rápidamente. En las elecciones de 1932, obtuvo 961 votos, y en las de 1937, 14.564. Ese año fueron electos los tres primeros parlamentarios del movimiento, teniendo así una representación en el Parlamento.

\section{El Ibañismo - La alianza popular libertadora}

La personalidad del General Ibáñez, influenció en la historia contemporánea del siglo XX en Chile; junto a su rival Arturo Alessandri, llenaron páginas y episodios de la época entre 1920 y 1958.

Carlos Ibáñez Del Campo nació en 1877, en el fundo de su padre, donde permaneció durante los primeros años de su niñez.

A los 12 años ingresó a un colegio primario, y luego secundario, en la ciudad de Linares. En 1896 ingresó a la Escuela Militar y comenzó su carrera militar con el grado de teniente. En 1903 participó en una misión en la República de El Salvador, donde se le concedieron los galones de Teniente Coronel, en mérito de sus servicios.

A su regreso a Chile fue ascendido a mayor. En 1920 fue designado Director de la Escuela de Caballería.

Tuvo un importante papel en los sucesos acaecidos entre 1924 y 1925, que llevaron a la promulgación de la constitución de 1925, constitución que provocó el cambio de República Parlamentaria a República Presidencial. 
En 1927 ocupaba el cargo de Ministro del Interior y General en Jefe del recién creado Cuerpo de Carabineros, única fuerza policial que existió en Chile con la unión de distintas policías locales, cuerpo que fundó Ibáñez.

El sucesor de Alessandri en la presidencia, fue Emiliano Figueroa, quien tuvo que renunciar por una maniobra política que hizo Ibáñez, acusando a su hermano, Presidente de la Corte Suprema, y obligando de esa forma, también a conseguir la renuncia del presidente. En 1927, y hasta 1931, ocupó la presidencia, como un acto dictatorial. Durante su período se realizaron numerosas obras públicas y reestructuración de los organismos nacionales. Ibáñez usó frecuentemente la represión, y abundaron los asesinatos realizados por sus agentes. En 1931, cuando Chile estaba sumido en la crisis económica mundial, se realizó una revuelta civil y estudiantil, que derrocó a Ibáñez quien se asiló en Argentina ${ }^{11}$.

En 1932 se realizaron nuevas elecciones presidenciales, cuyo ganador fue nuevamente Arturo Alessandri, quien encabezó un ministerio con los partidos de derecha, los mismos que en su primera administración le impidieron gobernar. El nuevo Presidente desechó a sus antiguos aliados, los estudiantes, y a los partidos comunista, socialista, radical y democrático.

En 1937 volvió del exilio el General Carlos Ibáñez del Campo. Los sucesos ocurridos en Chile, incluso la anarquía, que duró algún tiempo después de la caída de lbáñez, hicieron aumentar mucho su popularidad, fueron olvidados los abusos y el terror de su primera administración, y se le recordó como un hombre recto, fuerte en su carácter, que logró poner orden en el país, y por ello se le colocó en el mismo plano histórico que al legendario ministro Diego Portales.

Estando cerca las elecciones presidenciales, se organizó una amplia coalición, para apoyar su candidatura presidencial, en la que había partidos y organizaciones socialistas, grupos de independientes, y el Movimiento Nacional Socialista, que era el eje de esta combinación. Este movimiento se tituló Alianza Popular Libertadora. 
Los partidos de derecha, que gobernaban hasta 1938, lanzaron la candidatura del Ministro de Hacienda, Gustavo Ross Santa María, hombre de gran fortuna, que había acumulado en la bolsa de París. Durante el segundo gobierno de Alessandri sacó a Chile de los problemas financieros, que resultaron de la crisis económica mundial de 1931. Aunque muy hábil en los negocios, era muy impopular por su carácter, mirando a la gente del pueblo en forma muy despectiva. Lo apoyaron los partidos conservador, liberal y grupos independientes.

Los partidos de izquierda, inspirados en la creación en Francia del Frente Popular, promovían oponerse a los regímenes fascistas, que ya habían dominado parte de España en la Guerra Civil en ese país, formando conglomerados anti totalitarios y pro democráticos de tinte socialista o parecido.

Inspirados en ese ejemplo, se creó en Chile el Frente Popular, lo integraban los partidos Radical, Socialista, Comunista, Democrático y una pequeña fracción, separada del Partido Conservador, que sustentaba el Social Cristianismo, y que tomó como nombre Falange Nacional. Además tenían el respaldo de la Confederación de Trabajadores de Chile (C.T.Ch). Esta combinación levantó la candidatura de Pedro Aguirre Cerda, profesor secundario y abogado, que había desempeñado varios cargos ministeriales, en la época anterior a 1925.

La campaña electoral fue muy dura, y por ello, en 1938, los partidos del Frente Popular, pidieron una audiencia con el presidente Alessandri, pero este rehusó a atenderlos, y por ello los parlamentarios de esa combinación, decidieron perturbar el orden, en la sesión solemne de inauguración de las deliberaciones del congreso. La organización de ese evento, fue muy vigilada por personeros de la policía vestidos de civil, que estaban dentro del recinto de las reuniones.

Al comenzar Alessandri su mensaje, en un salón repleto de los parlamentarios de la Cámara de Diputados y el Senado, el Tribunal Supremo, y el Cuerpo Diplomático, el presidente fue interrumpido por 
el diputado radical, Gabriel González Videla, e inmediatamente los agentes de la policía lo expulsaron por la fuerza del recinto.

Se originó un pugilato entre los parlamentarios y el líder del Movimiento Nacional Socialista, González Von Marées, quien sacó un revolver e hizo varios disparos. Los detectives lo arrestaron, luego que lo sacaron del medio de los diputados y parlamentarios de la derecha, que deseaban lincharlo. Siendo Von Marées diputado, gozaba de fuero parlamentario, por ello fue detenido dentro del Parlamento, y bajo la vigilancia del presidente de la Cámara de Diputados.

Los dos candidatos, Ibáñez y Gustavo Ross, acaparaban, al parecer, la mayoría de los votantes, en cambio Pedro Aguirre Cerda y sus partidarios, no gozaban de gran popularidad, y por ello, los dirigentes de la Alianza Popular Libertadora, intentaron convencer a los partidos de izquierda, que apoyaran al General Ibáñez y retiraran la candidatura de Pedro Aguirre Cerda. Se destacó en esas negociaciones secretas, el dirigente radical Juan Antonio Ríos, que sucedería a Pedro Aguirre Cerda.

El 4 de Setiembre de 1938, la Alianza Popular Libertadora realizó un gran mitin y desfile, en el que participó un extraordinario número de gente. Al día siguiente, el 5 de Setiembre de 1938, un grupo de militantes del Movimiento Nacional Socialista (Naci) realizó un putsch (golpe de estado), apoderándose del edificio central de la Universidad de Chile, y del edificio del Seguro Obrero, próximo al Palacio de la Moneda, sede del presidente, desde donde los rebeldes podían atacar, debido a que la altura del edificio donde estaban era superior a la del Palacio Presidencial.

La mayor parte de los participantes en la revuelta eran estudiantes universitarios, miembros del partido naci, todos ellos muy jóvenes. Entre estos se encontraban varios descendientes de árabes, miembros de ese partido. 
El ejército actuó rápida y enérgicamente, con un cañón derribaron la puerta de la sede universitaria ocupada por los rebeldes, a los que condujeron al edificio de la Caja del Seguro Obrero, enviaron a uno de ellos para convencer a los que estaban atrincherados en ese edificio a que se rindieran, éstos convencidos de que así terminaría todo, depusieron sus armas. El ejército y la policía concentró a los dos grupos en un solo piso, y allí fueron masacrados, salvándose muy pocos de ellos. La matanza del Seguro Obrero, en la que perecieron más de sesenta muchachos, provocó gran indignación, y se transformó hasta el día de hoy, en una fecha de concentración de los nacis y nacionalistas.

La protesta nacional contra González Von Marées y su partido fue general. González Von Marées fue condenado a muerte, y una gran parte de sus partidarios, a penas máximas de prisión. El líder naci tomó para sí la responsabilidad de lo ocurrido, y denominó a los masacrados como sus: "locos heroicos".

Estos incidentes trajeron un profundo cambio en el Movimiento Nacional Socialista, que cambió su nombre a Vanguardia Popular Socialista e intentó acercarse a los partidos de izquierda, y en esa forma adaptó también en parte su ideología.

Los miembros del Frente Popular les propusieron un acuerdo, por el cual, los nacis apoyarían su candidatura, y si Pedro Aguirre Cerda resultaba electo, este promulgaría una amnistía general.

Lo interesante es que el Movimiento Nacional Socialista, no solo cambió su nombre, sino que condenó por un tiempo el antisemitismo, y estuvo a favor de la lucha de clases ${ }^{12}$.

\section{El fin del Movimiento Nacional Socialista}

La coalición gubernamental del presidente Pedro Aguirre Cerda no duró mucho tiempo en su estructura original. Los miembros de la Vanguardia Popular Socialista volvieron a retomar el carácter totalitario. 
En 1939 estalló un escándalo debido a una inmigración judía ilegal, que se produjo a consecuencia del pogrom de la Noche de Cristal, realizado en noviembre de 1938, que obligó a los judíos de Alemania, y del centro de Europa, a buscar refugio de la persecución nazi. El cónsul chileno en Bremen, Alemania, denunció irregularidades sobre los permisos de entrada a Chile de inmigrantes judíos. La acusación tuvo eco en el Parlamento, que decidió crear una comisión parlamentaria, para que investigara la acusación. El líder naci González Von Marées, que fue el informador de esa comisión ante el Parlamento, acusó a elementos del partido comunista, como organizadores y beneficiarios de las coimas pagadas por los inmigrantes judíos. La acusación se centró contra los diputados Pairoa, y Marcos Chamudes ${ }^{13}$, este último judío. La acusación fue rechazada por una estrecha minoría, y las consecuencias fueron: la renuncia del Ministro de Relaciones Exteriores y Colonización, Abraham Ortega Aguayo, y la prohibición total de entrada de judíos desde Enero de $1940^{14}$.

La Vanguardia Popular Socialista, realizó durante esta época una ola de terror, el diputado Bautista Rossetti, del Partido Socialista, fue agredido por los nacis, y tuvo que ser hospitalizado ${ }^{15}$.

El 16 de Marzo de 1941 se realizó el Congreso Nacional del Partido Radical, en esa ocasión una brigada naci, de la Vanguardia Popular Socialista, organizó un asalto a los congresistas radicales que se encontraban en la puerta del recinto, donde se realizaba el evento. El resultado fue que el senador Gustavo Girón y otros dos convencionales resultaron heridos de bala. El jefe del nacismo, González Von Marées, justificó el ataque y los demás que se realizarían, llamando nuevamente a los autores "mis heroicos locos".

Los ataques nacis continuaron durante todo el año 1941, causando la muerte de dos activistas socialistas: Manuel Bastidas y Héctor Barreto. 
La ola de terror realizada por los nacis aumentó la inquietud de los círculos políticos. En 1941 el nazismo alemán conquistaba casi toda Europa y parte del Norte de África y sus partidarios en Chile, pensaban que el advenimiento del nazismo en Chile era inevitable.

El Ministro del Interior, Arturo Olavarría Bravo, decidió poner fin a esta situación. Encontró que en el código sanitario, en el inciso 272, se daba el permiso de recluir en un manicomio a toda persona que se considerase insano mental. Existía un precedente, el senador Julio Martínez Montt estaba afectado por una enfermedad mental provocada por un trastorno de obsesión espiritista, el servicio médico, usando el inciso del código sanitario, lo detuvo y volvió a su puesto una vez que se curó de esa perturbación.

El Ministro Olavarría decidió usar este precedente con el líder nacista González Von Marées, y consiguió del Director de Beneficencia, una orden de internación en el manicomio para éste.

González Von Marées supo de esa decisión, a pesar de haberse dado con el mayor secreto, y recibió a los detectives que venían a apresarlo en su domicilio con tiros de revolver. El incidente tomó proporciones dramáticas, ya que la familia del implicado estaba en la casa, y fue testigo del tiroteo.

González Von Marées, por intermedio de sus abogados, planteó ante los tribunales un recurso de amparo, que el tribunal rechazó, pero una apelación a la Corte Suprema, le dio la absolución.

Según escribe Olavarría en su memoria, la acción realizada por él, puso prácticamente en disolución a la Vanguardia Popular Socialista, debido al desprestigio del jefe, a causa de la acusación de demencia.

También según escribe Olavarría, en la prensa inglesa se comentó que si algún ministro, en la Alemania Nazi hubiera hecho lo mismo con Hitler, el mundo se hubiera salvado de una catástrofe como la que ocurrió $^{16}$. 


\section{La creación del Movimiento Nacionalista de Chile}

En 1939, y luego del triunfo de Pedro Aguirre Cerda, se produjo un distanciamiento entre los sectores nacionalistas, que lamentaban el fracaso de su candidato presidencial Carlos Ibáñez del Campo, debido al putsch naci del 5 de Septiembre de 1938, que fue un fracaso y que motivó la renuncia indeclinable de Ibáñez, a presentarse como candidato a la presidencia.

Como ya lo hemos señalado, el partido naci realizó un cambio ideológico con aproximación a la izquierda, reconoció la lucha de clases y otras premisas extrañas al espíritu original de ese movimiento. Por ello numerosos activistas de ese partido se retiraron del mismo, ya que existía un vacío para ellos en el mapa político del país.

Después del triunfo del Frente Popular, los partidos de derecha, que habían perdido por un margen estrecho la elección presidencial, buscaron medios para eliminar el gobierno del frente popular, y organizar otro dictatorial, dirigido por algún general que llevara a cabo un programa nacionalista.

Los líderes de esos partidos encontraron como candidato ideal al general Ariosto Herrera, nieto del héroe de la Guerra del Pacífico Gral. Eleuterio Ramírez ${ }^{17}$. El Gral. Herrera había viajado por Italia y Alemania, quedando profundamente influenciado por los regímenes totalitarios de esos países.

Con motivo de la ascensión al poder de Pedro Aguirre Cerda, se realizó un comicio popular, el día en que el presidente electo asumía sus funciones.

Con ese motivo los partidarios del Frente Popular, realizaron un mitin en honor al presidente electo. En el mismo participaban los comunistas, aliados en el Frente Popular, y manifestaron llevando banderas rojas. El Gral. Herrera era el encargado del acto de juramento del presidente, pero se negó a actuar, hasta que fueran sacadas las banderas rojas. 
El Gral. Herrera, públicamente condenó al nuevo presidente, llamándolo "comunistoide". La actitud del general provocó temores en el nuevo gobierno, y por lo tanto, se lo llamó a retiro.

El 25 de Agosto de 1939 se presentó el Gral. Herrera, vestido con su uniforme de general, ante el cuartel del regimiento Tacna, importante cuerpo del ejército chileno, y anunció que se había declarado una revolución con el objeto de instaurar una dictadura bajo la dirección del Gral. Carlos Ibáñez del Campo, además anunció que se plegarían al movimiento otras divisiones, y pedía el apoyo a esa revolución del regimiento Tacna.

Pocas horas después de su llegada al cuartel de Tacna, apareció en ese lugar el Gral. Carlos Ibáñez del Campo.

El complot fue un rotundo fracaso, ningún otro cuerpo del ejército se adhirió a esa revolución, el comando del ejército leal al nuevo presidente, intervino enérgicamente, y los oficiales del regimiento Tacna, anunciaron su lealtad al gobierno.

El Gral. Ariosto Herrera abandonó el país, y el Gral. Ibáñez se refugió en la Embajada del Paraguay, y luego salió al exilio.

El fracaso de este complot, y la amargura de los elementos nacionalistas, frente a un gobierno de izquierda, que demostraba desde un principio su simpatía por los aliados, provocó la reacción de los nacionalistas, que eran simpatizantes del Eje.

Un profesor universitario de derecho constitucional, escritor y publicista, Guillermo Izquierdo Araya, organizó el Movimiento Nacionalista de Chile. 
Los adversarios de este grupo plantearon su ilegalidad, ya que Chile era un país democrático, y por lo tanto el régimen totalitario era ilegal.

El asunto fue llevado a los tribunales. Izquierdo Araya defendió ante los tribunales su posición, declarando que su partido era democrático, pero diferente a la democracia que existía ${ }^{18}$. El había formado un partido democrático corporativo, es decir, bajo la inspiración del facismo, y el entonces actual gobierno era democrático liberal. Por lo tanto no podía declararse ilegal a su movimiento, pues era democrático y sólo deseaba un cambio organizacional. El tribunal decidió permitir la creación del nuevo partido. El mismo duró pocos años, y su fracaso, entre otras causas, fue el triunfo de los aliados en Europa, y la aniquilación de los gobiernos de Hitler y Mussolini.

En 1941 la Vanguardia Popular Socialista cumplió su etapa en la política chilena, y se fue paulatinamente disolviendo. Su representación parlamentaria bajó ese año de tres a dos diputados. El desprestigio de González Von Marées provocó la deserción de numerosos adherentes, que pasaron al Movimiento Nacionalista de Chile.

Paralelamente a los acontecimientos narrados se organizó un grupo secreto de oficiales con el nombre de G. O. S. (Grupo de Oficiales Seleccionados). Este grupo fue descubierto por los servicios de investigación, por ello fue rápidamente disuelto, y su líder, el Cnel. Ramón Álvarez, fue trasladado a Punta Arenas.

El 25 de Noviembre de 1941, falleció el presidente Pedro Aguirre Cerda, y se convocó a nuevas elecciones presidenciales.

Varios grupos nacionalistas, entre ellos los últimos grupos de la fenecida Vanguardia Popular Socialista, levantaron la candidatura del Gral. Carlos Ibáñez del Campo. 
En cambio, el resto de los partidos, formó una coalición con el nombre de Alianza Democrática de Chile, que levantó la candidatura del radical Juan Antonio Ríos, conocido por su simpatía al Gral. Ibáñez, con el que colaboró en la época de la dictadura de éste. Por su parte los conglomerados que apoyaban al general, se unieron en un grupo que se llamó Unión Nacionalista de Chile.

En cuanto a la posición política internacional, la Alianza Democrática apoyaba a los aliados, y la Unión Nacionalista, a los países del Eje.

Arturo Alessandri, el rival del Gral. Carlos Ibáñez del Campo, volvió a la palestra política, para evitar que su partido, el partido liberal apoyara a Ibáñez. En un mitin consiguió convencer a gran parte de los liberales, que apoyaran a Juan Antonio Ríos.

Las elecciones presidenciales de 1942, arrojaron el siguiente resultado:

Juan Antonio Ríos

Gral. Carlos Ibáñez del Campo
$260.034-54,00 \%$ de los votos emitidos

$218.600-44,03 \%$ de los votos ${ }^{19}$

La derrota del Gral. Ibáñez no fue negativa para sus partidarios, desde ese momento el general se convirtió en el líder indiscutible del elemento nacionalista.

Los dos diputados de la Vanguardia Popular Socialista se agregaron a la Unión Nacionalista, terminando su mandato en 1945.

Los partidos que apoyaron a Ibáñez fueron: el Partido Conservador, parte del Partido Liberal, el Partido Laborista, La Unión Nacionalista, e independientes que apoyaban a Ibáñez. 
Los partidos que apoyaron a Juan Antonio Ríos fueron: radicales, socialistas, comunistas. Falangistas (grupo que se dividió del Partido Conservador, y que sostenía la doctrina "Social Cristiana"), una fracción del Partido Democrático y el sector alessandrista del Partido Liberal.

El final de la Segunda Guerra Mundial, y el triunfo de las democracias, provocó en 1945, una disolución de la Unión Nacionalista ${ }^{20}$. Una de las causas que llevaron a la disolución de la misma fue el triunfo de las democracias sobre los países totalitarios.

Chile en las postrimerías de la administración del presidente Juan Antonio Ríos, había roto las relaciones diplomáticas con los países del Eje, e incluso declarado la guerra al Japón.

Esta situación hizo perder la popularidad a aquellos grupos que habían apoyado a estos países, lo que debilitó el apoyo de una gran parte de sus simpatizantes.

En 1946 fue electo el nuevo presidente, Gabriel González Videla, apoyado por la coalición de los partidos de izquierda, y entre ellos con gran influencia esta vez, el Partido Comunista.

El creciente poderío del Partido Comunista y la política agresiva de la entonces Unión Soviética, provocó temor e indignación entre aquellos partidos y grupos que se habían colocado a favor de los Estados Unidos y los países democráticos, los que volvieron a revivir a círculos nacionalistas, entre estos grupos se encontraba el de la institución Acción Chilena Anti Comunista (A.Ch.A), que se organizó en forma paramilitar, haciendo entre sus miembros ejercicios militares y manteniendo cuarteles y todo lo necesario para una milicia política. El líder de esta organización fue el radical Arturo Olavarría Bravo.

La prepotencia comunista logró la reacción del presidente González Videla, que expulsó a ese partido del gobierno, luego promulgó la Ley de Defensa de la Democracia, que dejó al Partido Comunista como 
ilegal, borrando los nombres de sus miembros de los registros electorales. La nueva política del gobierno dejó sin causa a la A.Ch.A., que se disolvió.

Paralelamente a los esfuerzos para hacer revivir a las instituciones nacionalistas chilenas, un grupo de intelectuales de tendencias fascistas y nacionalistas decidió publicar una revista con el nombre de "Estanquero" (nombre que tenía relación con el ministro Diego Portales, al que ya hiciéramos alusión). El director de la revista era miembro del Partido Conservador, y los redactores eran miembros de los grupos nacionalistas, entre ellos, los que habían participado en el Movimiento Nacional Socialista, en la Alianza Popular Libertadora, y en grupos de partidarios del general Ibáñez. El editor de la revista era Jorge Prat, nieto de un héroe nacional Arturo Prat. La revista apareció entre los años 1946/1953. Su contenido era nacionalista, antiimperialista, apoyando a los movimientos nacionalistas, no solo de América Latina, sino que también al general Abdul Nasser, líder de la revolución militar egipcia, que intentó nacionalizar el Canal de Suez, lo que produjo una guerra contra los ejércitos inglés, francés e israelí, en 1956. La revista trajo a consecuencia de esto, varios artículos críticos sobre Israel y el pueblo judío. Además defendió al gobierno de Mosadeg, que en ese tiempo dominaba Irán e intentó realizar una nacionalización del petróleo de ese país.

La revista publicó artículos de defensa y admiración a los gobiernos de Juan Domingo Perón y Víctor Paz Estensoro.

En el plano nacional exigían la realización de una reforma agraria, y se identificaban con una tercera concepción política entre la izquierda y la derecha, siendo su ideario el nacionalista ${ }^{21}$.

\section{Partido Agrario Laborista}

En 1954 se fusionaron varios grupos políticos para constituir este partido. El principal factor de esta nueva organización fue el Partido Agrario. Este partido fue creado en 1931. Sus postulados eran 
regionalistas y defensores de los intereses agrícolas. Sus miembros originales eran principalmente agricultores de las zonas de Temuco y Cautín. En las elecciones de 1937, obtuvo dos diputados.

Otros componentes de este partido fueron los remanentes de la Alianza Popular Libertadora, y del Movimiento Nacional Socialista. Como se ve el nuevo partido estaba formado por grupos heterogéneos, cuyo principal propósito era conseguir el triunfo del General Ibáñez en las elecciones presidenciales, el dictador de los años 30. Por último se adhirieron también los miembros de la Unión Nacionalista, y del Movimiento Nacionalista de Chile. El partido se constituyó como tal el 15 de diciembre de 1945.

La línea política de este partido era nacionalista, contrario al sistema de partidos políticos, y a favor de un régimen corporativo, tomando como ejemplo los del gobierno de Franco en España y Salazar en Portugal, e incluso Mussolini ${ }^{22}$

A las elecciones presidenciales de 1952 se presentaron cuatro candidatos. Los partidos Liberal y Conservador, levantaron la candidatura de Arturo Matte; por su parte los socialistas postularon por primera vez la candidatura de Salvador Allende, los radicales a Pedro Enrique Alfonso y el cuarto candidato era el general Carlos Ibáñez del Campo.

La Propaganda de Ibáñez se basó en el deseo de limpiar la burocracia y la corrupción administrativa, teniendo un gobierno de fuerza como el de su anterior administración, que le permitiría llevar a cabo esos postulados. Su propaganda fue muy efectiva, tomando como símbolo una escoba, para demostrar que el deseaba limpiar la administración y la política.

Carlos Ibáñez del Campo resultó electo, obteniendo 446.439 votos, lo que significaba el $45,7 \%$ del total. El candidato mas próximo fue Arturo Matte, que recibió 265.337 votos, algo menos del 28 por ciento de los votos. 
La coalición de partidos y grupos que apoyaban al Gral. Ibáñez era muy heterogénea y vasta. Además del Partido Agrario Laborista, lo proclamó el Partido Socialista Popular y luego una serie de micro partidos y grupos gremiales, dirigidos por Mamerto Figueroa, que controlaba a varios sindicatos y María de la Cruz, líder del Partido Femenino, que se había organizado para defender los derechos de la mujer, y que tuvo un amplio apoyo, ya que se había reformado la ley de elecciones, participando la mujer con plenos derechos.

Las esperanzas de un gobierno fuerte quedaron truncadas. Carlos Ibáñez del Campo, decidió que en este período presidencial, se ajustaría totalmente a las prácticas democráticas, en contraposición a su primer gobierno, que esperaba mucho de sus partidarios.

Durante el gobierno de lbáñez reinó una semi anarquía, ya que el presidente cambiaba muy seguido la composición de su gobierno, además se produjo una gran inflación, con ella las reacciones y huelgas de los obreros y empleados, y la reacción del gobierno, que en muchas ocasiones usó la fuerza militar.

La consecuencia de esta situación provocó una desilusión entre los partidarios de lbáñez. El Partido Agrario Laborista se dividió, y luego retiró su apoyo a lbáñez, quedando éste prácticamente sin mayoría en el Parlamento, lo que le provocó muchas dificultades para gobernar. Como reacción a la situación se organizaron grupos militares, que deseaban volver a los principios autocráticos nacionalistas, dando al Gral. Ibáñez, la posibilidad de dirigir el país sin el respeto al régimen parlamentario y democrático. Un grupo se tituló "Línea Directa" y el otro se llamaba P.U.M.A. (iniciales de "Por una mañana auspiciosa").

Se complicó la situación del Gral. Ibáñez, cuando reforzó su relación con Juan Domingo Perón, y en cierta forma adoptó la doctrina justicialista del presidente argentino. Perón visitó Chile durante un largo tiempo, y realizó una serie de mítines, en los que insinuó la primacía de Argentina, cosa que ayudó a aumentar la impopularidad de Ibáñez. 
En 1957 se creó el Partido Demócrata Cristiano, formado por la Falange Nacional, grupo que se había dividido del Partido Conservador, y que había adoptado la filosofía social cristiana de Jaque Maritain, y una parte del partido conservador que se dividió en dos. El nuevo partido tuvo de inmediato un gran apoyo de amplios sectores de la clase media, y se transformó en una importante fuerza política que influencia a la política chilena. La otra parte mantuvo su política conservadora, agregando a su nombre la palabra tradicionalista, desde ese momento el Partido Conservador Tradicionalista, y el Partido Liberal formaron una coalición de gran influencia, como veremos mas adelante.

\section{El desarrollo de las ideas nacionalistas durante los gobiernos de: Jorge Alessandri Rodríguez (1958/1964) y Eduardo Frei (1964/1970)}

En 1958 fue electo presidente Jorge Alessandri Rodríguez (hijo del ex presidente Arturo Alessandri Palma), candidato independiente, que fue presentado por los partidos de la derecha, y algunos grupos nacionalistas.

Jorge Alessandri era ingeniero civil, e importante empresario. Políticamente era independiente, no perteneciendo a ningún partido, pero su orientación ideológica se acercaba al liberalismo. Fue electo presidente de Chile por el pleno del Parlamento, debido a un estrecho margen de votos entre él y su rival, el candidato de los partidos de izquierda, Salvador Allende. Parte de los partidarios de Alessandri eran los anteriores partidarios de lbáñez, que desengañados de este general, buscaban soluciones a los problemas de Chile, por medio de Jorge Alessandri.

La idea de Alessandri era que debía dirigirse el país en la misma forma que un empresario dirigía una empresa. El mismo Alessandri, fue, antes, durante y después de su presidencia, un importante empresario que dirigió grandes empresas.

Durante su gobierno se tomaron importantes medidas para mejorar las condiciones de la clase media, principalmente la construcción de casas con precios razonables para la burguesía. La orientación liberal 
de Alessandri chocó con la de los grupos nacionalistas. Estos últimos se oponían a los partidos políticos, que, según ellos, llevaban a Chile a la ruina, y el gobierno de Alessandri mantuvo su ejercicio con el apoyo del sector derechista del país. Además el sistema liberal se oponía a la idea del régimen corporativo fascista. Uno de los grupos que actuó de acuerdo a la ideología nacionalista, y que luego de apoyar a Alessandri se transformó en un opositor fue el Movimiento Revolucionario Nacional Sindicalista (M.N.R.S), grupo formado por intelectuales, en un principio como círculo ideológico, y que mantenía una línea de orientación católica militante. Su fundación se realizó en 1947. Desde 1963 se organizó como partido político. La ideología de este partido era la idea corporativa fascista, influenciada por los movimientos fascistas europeos de los años 30 del siglo XX, principalmente con el político ideólogo del fascismo español, José Antonio Primo de Rivera. Su oposición era a todo el sistema democrático, principalmente en contra de los partidos políticos, de izquierda y derecha. Para ellos debía cambiarse el régimen del país, por un gobierno central autoritario, cuya meta sería llevar el progreso a Chile por medio de una constitución corporativa. Creían que Chile debería ser el centro de todas sus actividades políticas y sociales. En 1964 el gobierno de Alessandri lo declaró ilegal, debido a sus principios fascistas y antidemocráticos. El M.N.R.S apeló ante los tribunales, que revocaron la orden del gobierno, según la ley de Seguridad del Estado, continuando con sus actividades, también en los futuros gobiernos.

En las elecciones presidenciales de 1964 fue electo como presidente el líder del Partido Social Cristiano Eduardo Frei Montalva, hijo de un inmigrante suizo, abogado y catedrático, que lideraba el reciente creado Partido Social Cristiano, que se produjo con la unión del Partido Conservador Social Cristiano, y la Falange Nacional.

Eduardo Frei quería realizar reformas sociales sin provocar convulsiones en el país. Entre sus programas se encontraba el deseo de realizar una Reforma Agraria, pero por la vía pacífica. Su posición se enfrentaba con las de los partidos de izquierda que pedían una reforma agraria compulsiva, basada en los ideales marxistas de la lucha de clases. La derecha, por su parte, se oponía a toda reforma agraria, 
aunque estaban dispuestos a convencer a algunos grandes hacendados, de donar algunos terrenos, a los campesinos no propietarios.

Otro grupo político, de orientación nacionalista y fascista, fue fundado por el economista Jorge Prat Echaurren. Durante el decenio del 50, editó la revista "Estanquero", que tuvo amplia difusión y se transformó en el vocero de todas las ideas que atacaban la democracia liberal, y la orientación marxista.

Además de la revista, Jorge Prat tenía gran popularidad, debido a ser nieto del héroe nacional Arturo Prat, que pereció heroicamente en la Guerra del Pacífico, en 1879.

Durante el gobierno de Jorge Alessandri, Prat realizó varias misiones, entre ellas fue el creador del Banco del Estado, pero al final del período presidencial de Alessandri, se marginó por no estar de acuerdo con el programa del presidente. Sus partidarios lo proclamaron en 1963, candidato a la presidencia de Chile, pero esa proposición no prosperó, debido a que se temía que la división de las fuerzas provocaría el triunfo de los grupos de izquierda. En 1964 sus partidarios crearon el Partido de Acción Nacional.

\section{La creación del Partido Nacional}

El 11 de Mayo de 1966 se formó el Partido Nacional por la unión de los partidos Liberal, Conservador Tradicionalista y Acción Nacional. La razón de esta actitud fue debido a la baja sensible del electorado de esos partidos. Su plataforma política declaraba ser un partido no confesional, lo que provocó el retiro de algunos conservadores que mantenían el ideal de un partido que defendiera a la Iglesia Católica. En el aspecto económico se identificaban con el liberalismo clásico. En el plano social el partido intentó dar preferencia al bienestar de la clase media. Otra premisa del partido, era el sentimiento nacionalista, tomando como modelo al legendario ministro Portales, de los años 30 del siglo XIX. Prat y su partido Acción Nacional, exigían colocar la doctrina portaliana como base principal de la ideología del Partido 
Nacional. Prat incluso opinó que debería darse el gobierno a los militares, que podrían desarrollar un gobierno patriótico y autoritario.

Al no ser aceptado este planteamiento, Prat y su partido abandonaron el Partido Nacional, pero varios de sus miembros, de gran influencia entre sus filas, se mantuvieron en el mismo, llegando a importantes posiciones, tanto en el Partido Nacional, como en el futuro gobierno de Augusto Pinochet.

\section{Los movimientos nacionalistas durante el gobierno de Salvador Allende}

Para las elecciones de 1970 se presentaron los siguientes candidatos: por los partidos de derecha e independientes, además de un sector que se dividió del Partido Radical, cuando éste decidió apoyar la candidatura de Salvador Allende, fue el ex presidente Jorge Alessandri Rodríguez. El nuevo partido, surgido de la división del radicalismo, se llamó Democracia Radical, y uno de sus líderes fue el ex senador de origen judío Angel Faivovich.

Los partidos de izquierda organizados en la Unidad Popular, plantearon la candidatura de Salvador Allende, senador, que había sido candidato a la presidencia durante varios períodos sin éxito, y que había sido ministro de salubridad en el gobierno de Pedro Aguirre Cerda. El principal partido sostenedor de esta candidatura era el Partido Comunista.

El tercer candidato, Radomiro Tomic, fue el candidato del Partido Social Cristiano, que había sido el partido que gobernó a Chile durante el gobierno de Eduardo Frei.

Los grupos de orientación nacionalista se encontraron frente a un dilema. Para ellos los partidos de derecha y de izquierda, eran contrarios al desarrollo del país, y al régimen corporativo que ellos deseaban instaurar, pero el peligro de que la Unidad Popular, y su abanderado Allende ganara la elección, les impulsó esta vez a apoyar la candidatura de Jorge Alessandri Rodríguez, aunque ese apoyo fue de corta duración. Un minúsculo partido que se denominó Partido Nacional Socialista Nazi, se 
alineaba con los grupos corporativistas. Este partido era liderado por Franz Pfeiffer, editando una publicación de nombre "Cruz Gamada", publicación que era apoyada económicamente por instituciones árabes, siendo su periódico altamente antisemita. A fines de 1969, se dividió este partido. Un sector liderado por Bernardo Moreno Vergara, atacó el liderazgo de Pfeiffer y logró expulsarlo por "inmoral". El conflicto interno llegó a los tribunales y el partido volvió a desaparecer ${ }^{23}$.

El resultado de la elección presidencial fue el siguiente:

Salvador Allende obtuvo 1.075.616 votos, o sea el $36,30 \%$ de los votos.

Jorge Alessandri Rodríguez obtuvo. 1.036 .578 votos, o sea el $31.80 \%$ de los votos.

Radomiro Tomic obtuvo 824.849 votos, o sea el $27,84 \%$.

Allende había conseguido una estrecha mayoría sobre su adversario. Según la constitución de 1925, para ser electo presidente se necesitaba recibir el $51 \%$ de los votos, en caso de no obtenerse esa cifra, la elección sería decidida por el Congreso Pleno en votación especial, y quien sacara la mayoría en esa votación sería el presidente.

En el Parlamento la mayoría de los partidos apoyaban a Alessandri, como el resultado de la elección fue muy estrecho, se pensaba que el Parlamento podría elegir como presidente a Jorge Alessandri, pese a que Allende había recibido la mas alta votación.

Jorge Alessandri rechazó esa proposición, declarando que la tradición había dado siempre el cargo de presidente a quien hubiera conseguido la mayoría, pese a no recibir el $51 \%$ de los votos.

Por su parte, la Unidad Popular entró en negociaciones con la Democracia Cristiana, juntos estos dos conglomerados, Allende tendría mayoría. El Partido Demócrata Cristiano decidió apoyar la candidatura de Allende, si este y sus partidarios firmaban un Acta de Garantía, que estipulaba que el nuevo gobierno no cambiaría la Constitución, ni las libertades que existían. 
Entre la elección presidencial y la ratificación del Parlamento hubo un período de algunas semanas. El pánico de numerosos sectores de la población por el peligro de que Allende transformara a Chile en una segunda Cuba, se agudizó con la visita de Fidel Castro durante un largo período en Chile y provocó una gran emigración de los adversarios de la Unidad Popular. Entre ellos muchos judíos que habían pasado en Europa, antes de su llegada a Chile, la opresión comunista en los países del Oriente Europeo ${ }^{24}$.

\section{El asesinato del General René Schneider}

A mediados de 1960 comenzó a organizarse en las filas del ejército, un movimiento de orientación nacionalista, que deseaba mejorar la situación de los miembros de las Fuerzas Armadas, que sufrían de diversos problemas, como falta de dotación, falta de materiales, infraestructura, etc. El principal motivo de la fundación de esta organización, fue la de mejorar los sueldos que recibían los oficiales del ejército. Este movimiento se inspiraba en las ideas totalitarias y adoptó la ideología nacionalista, se denominó Grupo Tacna, y culpó a los partidos políticos de no cuidar los intereses de Chile. La formación de este grupo provocó verdaderos motines por parte de sectores del ejército, que exigieron perentoriamente un inmediato aumento de sueldos.

A estas manifestaciones se adhirió el General de Brigada Roberto Viaux, comandante de la Primera División del ejército, ubicada en Antofagasta, que comenzó a planear un movimiento militar, que consistía en un acuartelamiento de todos los efectivos de la Primera División, desconociendo la autoridad del gobierno, impidiendo también la salida de los buques cargados de cobre que Chile exportaba, y que era la principal fuente de ingresos del país. Además logró que algunos efectivos militares de Santiago se plegaran al movimiento. El plan fracasó por haber tenido informe sobre él, el Comandante en Jefe Sergio Castillo, en una visita a la División de Antofagasta, a mediados de 1969, o sea, algunos meses antes de la finalización del gobierno del presidente Eduardo Frei. Como consecuencia de este descubrimiento el General Viaux fue llamado a Santiago. Viaux reunió y alentó a sus subalternos, aduciendo que se estaba tramando alguna acción en su contra. El 2 de Octubre de 1969, llegó el General a Santiago, e intentó por 
varios medios comunicarse directamente con el presidente Eduardo Frei Montalva, pero éste rechazó ese pedido y envió el caso de Viaux a la Junta Calificadora de Oficiales, la que decidía sobre los ascensos y retiros del ejército. La Junta Calificadora de Oficiales dio de baja a tres generales, Manuel Pinochet, Florian Silva y Roberto Viaux. Este último se negó a cursar su retiro e intentó organizar un golpe de estado, y para ello visitó varios cuerpos del ejército. El 17 de Octubre se tuvo conocimiento público de las actividades de indisciplina del general Viaux. Este último aumentó la tensión, cuando entregó una declaración pública firmada por 70 oficiales, y reproducida por el diario El Mercurio, que exigía como acto inmediato reponer al Gral. Viaux en su puesto. El gobierno nombró como sucesor de Viaux, al Gral. Galvarino Mandujano para tomar el cargo de la división. Viaux llegó a Santiago el 20 de Octubre, haciendo declaraciones, en las que manifestaba "velar por la situación del ejército" amenazando: "Llegaré hasta donde sea posible".

El 21 de Octubre Viaux tomó el mando del Regimiento Tacna, al que se plegaron otros grupos militares. El Presidente declaró el Estado de Sitio, y en una cadena nacional de radio condenó la maniobra de Viaux, y el peligro de la posibilidad de una dictadura.

El Regimiento Tacna, y otros grupos militares se declararon en rebelión. Viaux hizo colocar altoparlantes, para informar los comunicados y sus intenciones.

La reacción popular fue de adhesión al gobierno, y se le amenazó que se daría armas al pueblo para hacer fracasar esa revolución. El gobierno transó, haciendo renunciar al Ministro de Defensa, y al Comandante en Jefe del Ejército. Varios generales firmaron un documento, conocido como el "Acta del Tacna". Viaux reunió sus partidarios, y declaró su derrota y luego fue detenido.

El Movimiento Tacna, o Tacnazo, como fue bautizado por la prensa, fue la primera señal de la posibilidad de un levantamiento militar contra un gobierno civil. 
El Gral. Viaux, ya en retiro, continuó dirigiendo un grupo de oficiales y civiles, que actuaban sin manifestaciones externas, y que vieron con profundo temor la subida al poder de los partidos de izquierda, en especial el comunista.

Esa preocupación era compartida por los servicios secretos norteamericanos, la CIA. Estos círculos comenzaron a planificar una acción, destinada a evitar que Allende subiera al poder, a pesar de la decisión de entronizarlo como presidente. El líder seguía siendo el Gral. Viaux, y con él, el Gral. Camilo Valenzuela.

El plan consistía en secuestrar al General en jefe del ejército, Gral. René Schneider, que era leal al régimen democrático. Una vez capturado y escondido, se podría colocar como condición para liberarlo, la anulación del acuerdo de nombramiento de Allende como presidente.

La CIA prestó apoyo, tanto financiero como de armamentos. Dirigía esta maniobra en Estados Unidos Henry Kissinger, aunque éste alegó posteriormente, ante la Corte Suprema de Estados Unidos, que su responsabilidad fue política, pero no militar.

El 23 de Octubre de 1970 en Santiago, el auto del Gral. Schneider fue interceptado por un grupo armado, que intentó secuestrarlo. El Gral. Schneider intentó resistir, y usar su arma, pero los miembros de ese comando lo asesinaron. Su asesinato tuvo una consecuencia totalmente contraria a los deseos del Grupo Tacna, una parte de los autores huyó hacia la Argentina y otros al Paraguay.

\section{Los otros grupos nacionalistas y el Gobierno de Salvador Allende}

Al asumir la presidencia Salvador Allende intentó, junto a los partidos que dirigían su coalición, comenzar inmediatamente un plan de estatización de las grandes empresas económicas. 
Las organizaciones nacionalistas, de tinte fascista o totalitaria, comenzaron inmediatamente a tener una actitud altamente de rebeldía ante el nuevo gobierno. Los principales grupos de esa oposición eran: el Partido Nacional, el Movimiento Revolucionario Nacional Sindicalista, y el Frente Patria y Libertad.

El Partido Nacional, junto a la Democracia Radical, centralizó su acción opositora en el Parlamento, y editó un diario de nombre "Tribuna", que tuvo varias publicaciones antisemitas.

El caso mas notable fue lo ocurrido en un programa de televisión, en que se atacó duramente a los capitalistas árabes, y en especial a la firma Yarur, además se proyectó un cortometraje sobre Israel, alabando al país, y condenando los ataques terroristas. Este programa provocó una conmoción nacional, en primer lugar en la numerosa y poderosa comunidad árabe de Chile, pero también del Partido Nacional, que en su diario "Tribuna", atacó a una cantidad importante de judíos que tenían puestos públicos en el nuevo régimen ${ }^{25}$.

El movimiento de mayor importancia en el fin del gobierno de la Unidad Popular, con el trágico suicidio de Salvador Allende, fue el Movimiento Patria y Libertad, partido neofascista que decidió actuar por la situación política y económica en la cual se encontraba el país, intentando influenciar en un nuevo sistema político, corporativista y portaliano. Este movimiento tomó fuerza y se amplió a sus adherentes, a medida que Chile entraba en una crisis de desabastecimiento y de agitación política. El líder de este movimiento fue el abogado Pablo Rodríguez Grez, vinculado en sus actividades con compañías norteamericanas y otras multinacionales, y simpatizante del Partido Nacional. Durante la campaña presidencial, apoyó a Jorge Alessandri Rodríguez. Hasta la elección de Allende, el movimiento era extremadamente minoritario, apenas unas cincuenta personas y luego, al polarizar los ataques contra el nuevo régimen, fue tomando fuerza, y a finales de 1972, sus miembros ascendían a diez mil, saludando con el signo nazista de la mano extendida, y desfilando por las calles de Santiago. A este movimiento se adhirieron numerosos grupos juveniles patrióticos y tradicionales. Rodríguez llamó a la constitución de un frente juvenil, que se denominó Frente Nacionalista, del que asumió prácticamente el control desde el 
primer momento. Integraban esta organización la juventud del Partido Nacional, un grupo llamado Comando Rolando Matus, el Movimiento Revolucionario Nacional Sindicalista, y formando su parte principal, la organización de Patria y Libertad. Se marginaron el grupo de Franz Pfeiffer, y otros grupos más pequeños, e incluso los restos del Grupo Tacna. Sus agentes comenzaron a infiltrarse en las Fuerzas Armadas, y hubo un intento de revolución militar, dirigida por el coronel Roberto Souper, jefe del Segundo Regimiento Blindado, revolución que fracasó al cabo de pocas horas. Se creyó que Souper había fallecido en un accidente de aviación, pero en realidad huyó a Argentina, y volvió a Santiago para reorganizar al movimiento, ya declarado ilegal, y preparar la lucha contra Allende. Descubierto, fue detenido el 26 de Agosto, tres semanas antes del golpe militar que derrocó a Allende. El líder de Patria y Libertad, junto con otros cinco líderes del movimiento, se asilaron en la Embajada de Ecuador, donde estuvieron hasta la subida al poder de Augusto Pinochet.

\section{Los movimientos nacionalistas durante el Gobierno de Augusto Pinochet}

Una de las primeras medidas del régimen militar fue publicar el Bando Nro. 2, que declaraba en receso a todos los partidos políticos. Los partidos nacionalistas, que veían en la revolución militar la realización de sus aspiraciones, aceptaron el bando referido, y muchos de sus ex miembros se integraron en los puestos gubernamentales.

Los miembros del ex movimiento Patria y Libertad, en su mayoría, ocuparon cargos en distintos ministerios, los miembros del Movimiento Revolucionario Nacional Sindicalista, se activaron en el marco de los gremios y del estudiantado universitario.

Podemos dividir para nuestro tema, el período de Augusto Pinochet en dos fases: la primera comprende el período desde la formación de la junta militar, hasta el asesinato en Washington del ex Ministro de R.R.E.E. del gobierno de Allende, Osvaldo Letelier, y la segunda fase comienza con el asesinato de Letelier y el enfriamiento de las relaciones con los E.E.U.U., debido al crimen referido, que coincidió con 
el cambio de administración en Estados Unidos, con el fin del período Nixon y con él el fin de la guerra de Vietnam, y la subida al poder del Partido Demócrata liderado por Edward (Ted) Kennedy.

El primer período se caracterizó por una feroz represión a los adversarios del nuevo régimen, principalmente al Partido Comunista, y al M.I.R. (Movimiento de Izquierda Revolucionaria). El gobierno creó una poderosa organización policial, que se encargaba en especial de los enemigos del régimen ${ }^{26}$, ya sea viviendo en Chile, o exilados en el exterior. Las dos víctimas mas importantes asesinadas en el extranjero, fueron el ex comandante en jefe del ejército, Gral. Carlos Prats, que se había opuesto a la revolución militar, y que fue asesinado en Buenos Aires en 1974, un corto tiempo después que se produjo dicha revolución, y en 1976 fue asesinado Osvaldo Letelier en la ciudad de Washington. En el plano nacional la DINA asesinó a centenares de opositores al régimen.

La opinión pública mundial, y especialmente la estadounidense, levantó protestas contra esos crímenes, que fueron en muchos lugares organizadas por los numerosos exilados chilenos.

El gobierno demócrata norteamericano anunció un cambio total en la política de los E.E.U.U. En la época de Nixon, la DINA actuó en estrecho contacto con la Oficina de Inteligencia del Estado Norteamericano (C.I.A.), la que financió todas sus actividades. En cambio la administración actual, no solo canceló su ayuda al gobierno de Pinochet, sino que realizó un embargo de venta de armas a Chile, las cuales necesitaba porque existía un peligro de guerra entre Chile y Argentina, por la zona del Beagle. Además, el gobierno norteamericano exigió la captura y castigo penal a los agentes de la DINA, que habían perpetrado estos atentados.

Por ello en la segunda época del gobierno de Pinochet, hubo algunos cambios importantes, se disolvió la DINA, creándose un nuevo organismo policial, más moderado que el anterior, y en el gobierno ingresaron en forma progresiva civiles, sobre todo economistas, discípulos de Milton Friedman, los llamados "Chicago boys". 
Una organización nacionalista fue creada por el gobierno, con el nombre de "Avanzada Nacional".

En las postrimerías del gobierno de Pinochet, volvieron a renacer grupos y personas adictas al nazismo. Su ideólogo era Miguel Serrano, diplomático y escritor, que había sido representante de Chile en la India, en ese país fue influenciado por las doctrinas religiosas del Oriente, a las que agregó sus experiencias en Europa, y con ellas su admiración por Hitler y su ideología. Trató de crear una seudo filosofía, que llamó "nazismo esotérico". Entre sus pertenencias tenía un cuadro pintado por Hitler.

Serrano publicó numerosos libros y artículos, participando abiertamente en la actividad nazista, hasta su muerte en el año $2009^{27}$.

\section{Los movimientos nacionalistas después de la caída de Pinochet}

La caída del Gral. Pinochet, ocurrida en las postrimerías del decenio 90 del siglo XX, provocó un cambio total en el sistema político chileno. Pinochet fue derrotado y pasó a ser senador vitalicio, y Comandante en Jefe del Ejército por algunos años más. Posteriormente fue detenido en Londres, donde había ido a tratamiento médico, en base a una denuncia del fiscal español Garzón y luego de un bullado proceso tuvo que renunciar a todos los puestos, falleciendo en el año 2006 a los 91 años de edad.

Los diecisiete años de su gobierno provocaron un cambio sustancial en el mapa político chileno. Los antiguos partidos de la derecha dejaron de existir, en cambio, se crearon dos nuevos partidos, que son de derecha y de centro derecha, el Partido Renovación Nacional, que agrupa generalmente a los elementos que anteriormente eran conservadores y liberales y la Unión Democrática Independiente (UDI), que fue formada por gremios, que luego se alinearon en la ideología de derecha, y posteriormente, junto con el Partido Renovación Nacional, formaron un frente de derecha, que se opuso a los gobiernos de la llamada Concertación (Partido Demócrata Cristiano, Partido Socialista, Partido Radical Democrático 
y Partido por la Democracia), formación que llevó a la presidencia a Patricio Aylwin, Eduardo Frei Ruiz Tagle, Ricardo Lagos y Michel Bachelet.

El Partido Comunista quedó muy disminuido, tanto por los años de su represión, como por los cambios ocurridos en Rusia y sus satélites, teniendo hoy en día un pequeño volumen electoral, lo mismo que un "partido verde", que adoptó el ideal de defensa a la naturaleza. En muchas ocasiones los comunistas y los verdes actúan en colaboración.

\section{Congreso mundial del nazismo en Chile}

Los nazis y nacionalistas volvieron a levantar cabeza. Un dirigente de Renovación Nacional, expulsado posteriormente del partido, creó uno nuevo con el título de Movimiento Patria Nueva y Sociedad, cuyas siglas coinciden con las del Partido Nacional Socialista. El líder de este partido, hijo de un veterano militante del partido nazi, se llama Alexis López, hombre de antecedentes penales notorios, fue procesado por el pago con cheques sin fondo, y su empresa quebró, pero supo dar vida a este renacido movimiento nazi. En el año 2000 convocó a un congreso internacional de los movimientos nazis de América Latina y del mundo, con el objeto de planificar la actividad nazista en el siglo XXI. La convocatoria a este congreso provocó un clamor público en Chile, la colectividad judía y el Congreso Judío Latinoamericano, exigieron la prohibición de ese encuentro, propuesta acogida por el gobierno, que dio instrucciones a la policía y a los servicios de identificación en los aeropuertos, para impedir la entrada de nazis extranjeros al país, publicando además un decreto prohibiendo dicho congreso. A pesar de la prohibición y de las medidas tomadas, una treintena de dirigentes nazis de países latinoamericanos, de Francia, Alemania y otros, llegaron al país y realizaron un encuentro, aunque sin publicidad.

Distintos partidos y parlamentarios presentaron un pedido ante el Tribunal Constitucional, pidiendo que ese partido fuera declarado ilegal. En el juicio los miembros del partido Patria Nueva y Sociedad, declararon que ellos no eran nazis, sino neo nazis, que el nuevo movimiento había borrado de su ideología el racismo y principalmente el antisemitismo, y que habían decidido no actuar mas con métodos 
de terror. El Tribunal no los borró de los registros, tomando en consideración las explicaciones de sus líderes.

Una nueva iniciativa para ilegalizar a este partido, de acuerdo a la legislación anti racista, fue presentada ante el Tribunal Constitucional en Junio del 2010, que consultó a la Agencia Nacional de Inteligencia (ANI), para fallar en ese sentido. El Tribunal Constitucional concluyó que el Movimiento Patria Nueva y Libertad condena el racismo, se opone a la violación de los derechos humanos, y afirma no ser antisemita, sino antisionista, es decir se oponen al nacionalismo (israelí), por lo tanto no representa una amenaza, basándose en la Convención Europea de Derechos Humanos. El Tribunal Constitucional hizo ver que hacer inconstitucional a una organización política solo puede tener lugar frente a casos más graves, o amenaza real para la Constitución ${ }^{28}$.

Otros grupos más pequeños, formados por la influencia de la actividad de los grupos "cabezas rapadas", han desarrollado una acción agresiva, racista, antisemita y homofóba. Esos grupos han sido reseñados en el libro del profesor Isaac Caro, que contiene una lista completa, no solo de los grupos en Chile, sino también en otros países latinoamericanos ${ }^{29}$.

\section{Las colectividades extranjeras en Chile y la ideología totalitaria}

Los extranjeros en Chile no fueron numerosos. Se calcula que en un lapso de 100 años, el número de estos inmigrantes no alcanzó a los cien mil, y la mayor parte de ellos estaba diseminada por todo el territorio chileno. La excepción fue la de las comunidades alemanas e inglesas.

Todas las comunidades extranjeras tienen una misma característica, que es una dualidad entre sus sentimientos por Chile, y por su país de origen. 
La colonia inglesa se concentró, en su mayoría, en las ciudades de Santiago y Valparaíso, su característica principal, que la diferenciaba del resto de la población chilena, era su fe protestante anglicana o evangélica. En los primeros tiempos tuvieron que luchar por poder mantener su fe, pero en el transcurso del siglo XIX, lograron que se les respetaran en sus creencias, y desde 1865, año que se reformó la Constitución de 1833, permitiendo la libertad de cultos, no solo prosperaron sus templos, sino que se acrecentaron, gracias a la labor proselitista, y hoy día, el protestantismo en Chile es una corriente numerosa e importante en el país.

A fines del siglo XIX, comenzó el auge de la minería en el norte de Chile, el principal capital inglés lo aportó un especulador inglés de nombre North, quien logró, gracias a combinaciones bancarias en Londres, a base de la venta del salitre y el cobre en ese país, realizar una gran fortuna y transformarse en un poderoso magnate, que influenció en la política chilena, al punto de ser uno de los principales autores del Movimiento Revolucionario contra el presidente Balmaceda, que provocaron la Guerra Civil de 1891, el suicidio del presidente Balmaceda, y la transformación de Chile, desde 1925, en una República Parlamentaria y no Presidencial.

Como toda colectividad extranjera, se sintieron rápidamente aclimatados en el país, llegando algunos de sus miembros y sus hijos, a puestos de primera importancia en la vida política y cultural del país, pero, continuaron manteniendo una lealtad hacia su patria de origen, o a la de sus padres. Durante toda su existencia, las colonias norteamericana e inglesa, mantuvieron estrecho contacto con sus embajadas y visitando de vez en cuando, su país de origen.

Durante la Primera Guerra Mundial, ingleses y norteamericanos se enrolaron en las filas de los ejércitos de esos países. No solo los nacidos en ellos, sino también sus hijos, igual ocurrió durante la Segunda Guerra Mundial. Algunos murieron en la batalla, y los que quedaron en Chile, ayudaron, ya sea con envíos de dinero, o colaborando con su embajada, en el intento de impedir la actividad comercial entre Chile y los enemigos de los países natales. 
La otra colectividad extranjera, que generalmente se concentró en una zona, fue la colectividad alemana. El origen de la colonización alemana en Chile, se remonta a la primera mitad del siglo XIX, principalmente después de 1848, cuando un grupo de alemanes residentes en Valparaíso, impresionados por la derrota del Movimiento Liberal y Nacionalista en Alemania, decidieron crear en el sur de Chile, en la región de los indios araucanos, y en las zonas semipobladas al sur de esos territorios indígenas, colonias de inmigrantes alemanes, que en esas zonas tendrían la garantía de vivir democráticamente, y de preservar sus costumbres religiosas.

La colonización alemana en el sur de Chile, fue un gran éxito, pese a su relativo pequeño número, los alemanes consolidaron y lograron la creación de nuevas ciudades y barrios en ciudades que ya existían.

Con el tiempo, creció el nacionalismo alemán, y los gobiernos de Prusia se interesaron en ayudar a esos inmigrantes, enviando maestros y creando escuelas que subvencionaban. La creación del estado alemán, unido bajo la hegemonía de Prusia, aumentó en los colonos alemanes en Chile, el orgullo por su nacionalidad.

También los alemanes e hijos de alemanes partieron a luchar por su país en la Primera Guerra Mundial.

La derrota de Francia en 1870,y el impresionante poderío alemán provocó el deseo del gobierno chileno, de cambiar la estructura del ejército de su país, que seguía el modelo del ejército francés, y transformarlo en un ejército orientado y dirigido por oficiales alemanes contratados para esto. El triunfo de Chile en la Guerra del Pacífico, demostró que la medida tomada era efectiva, y desde ese momento, oficiales alemanes trabajaron en Chile, y oficiales chilenos viajaron a estudiar en Alemania ${ }^{30}$. 
Además del aporte alemán al ejército chileno, está el aporte importante en la educación primaria, secundaria y universitaria del país. El gobierno chileno contrató profesores alemanes, y durante un largo tiempo fueron los factores más importantes del desarrollo educativo en Chile.

La derrota de Alemania en la Primera Guerra Mundial, provocó consternación en Chile, pero se continuó la relación militar entre los residentes alemanes. Chile envió numerosos oficiales para perfeccionar sus conocimientos, pese a que en Alemania había grandes restricciones, ya que el acuerdo de Versalles impedía el rearme de Alemania, y solo se le permitía un pequeño ejército.

Con el advenimiento de Hitler, y su ascensión al poder en 1933, se formó en la colectividad alemana del sur de Chile, los primeros núcleos de esa ideología en el país ${ }^{31}$.

En Enero de 1933, subió Hitler al poder en Alemania, y comenzó su agitación antisemita. La colectividad judía de Chile realizó mítines de protesta en numerosas ciudades, que tuvieron acogida en un gran número de personas judías y no judías, la prensa dedicó crónicas destacadas a esas reuniones. Esta actividad tuvo eco en la Cámara de Diputados, cuando algunos parlamentarios exigieron el envío de una nota de protesta por la persecución de judíos. Se opuso a esta proposición el diputado de origen alemán Edwing, diciendo que no había persecuciones de judíos en Alemania, que eso era producto de un complot del judaísmo internacional, que dominaba la prensa mundial, además recalcó que en ese entonces había un grupo de judíos miembros del Partido Nazi Alemán (que fueron posteriormente liquidados en los campos de concentración).

Con el comienzo de la Segunda Guerra Mundial se organizó un movimiento nazi, que era orientado y dirigido desde Berlín, por un departamento especial que había creado el régimen hitleriano, para organizar a las comunidades alemanas, como apoyo material y estratégico a los designios de Hitler. Los nazistas habían puesto los ojos a las comunidades alemanas del sur de Brasil, en el estado Río Grande del Sur, ya que esos inmigrantes eran mayoría en muchos puntos de ese estado, lo mismo ocurría en 
Chile en la zona sur del país, lo que permitía pensar a los nazis, la posibilidad de crear su primera fase de la dominación del continente americano en su plan de dominar al mundo. La central en Berlín, que se dedicaba a propagar el Nacional Socialismo, creó en el sur de Chile, la Organización Juvenil Alemana, que fue dirigida por Rodolfo Schwatzberg, que mantenía su contacto con Alemania, y no con el Partido Nacional Socialista Chileno (Naci), este último acordó expulsar del partido a los sectores alemanes leales a Berlín, anunciando que el partido chileno no tenía una ideología de servicio a Hitler y a su partido en Alemania $^{32}$.

La actividad de los nazistas del sur fue muy vasta, persiguiendo a los antinazis, y realizando numerosos desfiles militares en las distintas ciudades del país. El embajador norteamericano en Chile, que visitó el sur del país, quedó impactado de la fuerza de ese movimiento ${ }^{33}$.

La actividad nazista en el sur provocó una acusación en la Cámara de Diputados, que fue patrocinada por algunos parlamentarios, entre ellos, algunos de origen alemán, y como consecuencia se creó una Comisión de Investigación de la actividad nazi en el sur del país, tomándose serias medidas contra esa situación, incluso llevando a la cárcel a algunos de los cabecillas. Con la entrada en la guerra de los Estados Unidos y de Rusia, aumentó en Chile el deseo de apoyar la causa democrática, como fue también acordado en los congresos latinoamericanos, que se adhirieron a los EEUU, para evitar la posible invasión alemana al continente.

La guerra afectó también a Chile, debido a la actividad de los submarinos alemanes en el Pacífico. La organización nazi alemana de Chile organizó un sistema de espionaje, para saber el movimiento de los barcos, que serían presa de los submarinos alemanes. Los servicios de contraespionaje norteamericanos descubrieron esta maniobra, procediéndose a arrestar a sus miembros, entre ellos figuraba un judío, que tenía como nombre clave el de Manolo, que al ser detenido manifestó, que el estaba de acuerdo con toda la ideología nazi, menos la persecución de los judíos ${ }^{34}$. 
En 1943 Chile rompió relaciones con Alemania y sus aliados, y en 1944 declaró la guerra al Japón.

Los españoles son la colectividad más antigua existente en Chile, su origen fue la dominación española antes de la independencia. Al crearse la República de Chile, muchos de los españoles adoptaron la ciudadanía chilena, otros abandonaron Chile, continuando la guerra de independencia, en el lado español.

Hubo ejemplos trágicos entre muchas familias, como el Gral. Bulnes, futuro presidente de Chile, que era hijo de un coronel español, que continuó luchando contra Chile, muriendo en campaña en el Perú.

Hasta 1879, la situación de los españoles que se quedaron en Chile sin obtener la ciudadanía chilena, fue objeto de la hostilidad y el desprecio de los patriotas chilenos. En 1866 se declaró una guerra entre Chile y España, los españoles bombardearon Valparaíso, ciudad que no estaba fortificada, y Chile obligó a los residentes españoles a pagar las indemnizaciones por los perjuicios recibidos.

Esta situación provocó el contacto familiar entre españoles que regresaban a España, y sus parientes chilenos, de ahí que los nexos entre los dos países no fueron solo económicos o militares, sino que familiares.

La colectividad española hasta 1882, fue una comunidad católica, habiendo creado colegios, conventos e iglesias para ellos. Su lealtad hacia España era principalmente religiosa. Con los cambios políticos en España, y con el aumento de la inmigración española al país, se transformó el sentido de nacionalidad de religioso a político.

En 1898 estalló una guerra entre España y los EEUU, los españoles en Chile recolectaron fondos, legalizaron actividades en apoyo a España, juntando en colaboración con las colectividades en Perú y Bolivia, una gruesa suma de dinero, para ayudar a la marina española. 
Ya a fines del decenio 90 del siglo XIX, empezó a dividirse el núcleo español en instituciones regionales como ser, el centro asturiano, el centro catalán, el centro vasco. Además los diferentes partidos políticos en España, y las luchas internas, incluso asesinatos, tuvieron repercusión en la colectividad española. En todo caso, la mayor parte de los españoles que residían en Chile en esta época eran de orientación católica, nacionalista, y conservadora. Su nexo con la Iglesia Católica, les hacía participar en las actividades del Partido Conservador, que en esa época, era partidario de mantener un estado católico excluyente, pero la nueva inmigración española trajo a Chile elementos socialistas y anarquistas, posteriormente comunistas, los que provocaron una agitación social que alarmó a los partidos de gobierno, que promulgaron la Ley de Ciudadanía en Diciembre de 1918, en la que dieron facultad al gobierno para expulsar, sin juicio, a todo extranjero que se dedicara a actividades de agitación social. Algunos perecieron debido a los tormentos en los calabozos de la policía chilena. Desde el fin del siglo XIX, comenzaron a llegar a Chile otros personeros adeptos al sistema republicano, algunos de ellos se dedicaron al periodismo, otros fundaron editoriales.

El resultado de esta nueva inmigración fue la creación del Centro Republicano Español, que aglutinó a los españoles que deseaban para su país ese sistema de gobierno.

La subida del nazismo y la Guerra Civil Española, provocada con la ayuda de Alemania e Italia, y resistida por los partidos y movimientos de izquierda, dio como resultado la derrota de las fuerzas democráticas, y el advenimiento del régimen franquista, bajo la dirección del Gral. Franco.

Miles de españoles abandonaron España, buscando lugares de refugio. El gobierno chileno, dirigido en esa época por el Frente Popular, abrió sus puertas a miles de estos refugiados. La colectividad española en Chile se dividió entre aquellos que apoyaban al régimen de Franco, fundamentalmente los elementos católicos conservadores, y los que apoyaban al gobierno republicano español en el exilio. 
En conclusión, el elemento español mantuvo su lealtad a España, pero también a sus convicciones de la madre patria.

Una situación parecida tenemos entre los italianos, los chinos, los árabes, judíos y otras colonias extranjeras. Todos estos grupos mantienen su identidad nacional, pero su lealtad sincera a Chile.

\section{Conclusiones}

Las ideas nacionalistas en Chile existieron desde su creación como país, y se mantuvieron durante los doscientos años de Independencia del mismo, sin embargo, solo en contadas ocasiones tuvieron las fuerzas políticas, inspiradas en esas ideologías, una influencia estable en la marcha del país.

Las bases ideológicas del nacionalismo chileno tienen varios orígenes: el espíritu religioso católico, heredado de la época de la Colonia Española en el país; el espíritu militar, que tuvo gran influencia en la formación del pueblo chileno durante los siglos de enfrentamiento bélico con los indios araucanos, con los piratas que visitaron Chile durante distintos períodos, y con las guerras que tuvo Chile contra España en 1866 y contra Perú y Bolivia en 1879-1880. Aunque el régimen interno fue sólido, debemos agregar algunas revoluciones y asonadas, que ocurrieron de tiempo en tiempo y que también fortificaron el espíritu guerrero de la sociedad chilena.

Durante varios decenios, el régimen político imperante en Chile fue el de una república autocrática, dirigida por las clases acomodadas. Esta situación provocó el ideal de un estado con gobierno estable y con instituciones republicanas sólidas.

En los primeros años de la República, y hasta 1830, existió una anarquía producto del intento de fortificar al nuevo estado. En ese intento se perfiló la figura del ministro Portales, al que ya nos hemos referido. 
Pese a la estabilidad del país, hubo épocas de crisis, como la Guerra Civil de 1891, que derrocó al Presidente Balmaceda, o los acontecimientos sociales que azotaron al país durante los decenios del 20 y 30 del siglo XX. Estas crisis fueron acompañadas por situaciones mundiales que llevaron a numerosos países del mundo a una recesión económica.

Los movimientos sociales y políticos de Europa influenciaron a la política chilena durante toda su historia. La revolución que trajo la independencia en 1810 fue el reflejo de las guerras napoleónicas en Europa. Las raíces de las ideas socialistas comenzaron después de las revoluciones de 1830 y 1848 , revoluciones liberales contra estados autocráticos.

La crisis económica mundial de 1929 a 1931 provocó no solo una inestabilidad política, sino que también la implantación de una dictadura dirigida por el General Ibáñez, cuyas bases eran volver a la tranquilad pública e implantar un orden diferente al democrático. También en esa época los sucesos ocurridos en Europa entre los decenios 20 al 40 del siglo $\mathrm{XX}$, trajeron las ideologías corporativistas, fascistas y nazistas.

Finalmente, el régimen de Pinochet es el último que conocemos, que realizó un intento serio y largo para cambiar las normas democráticas, e instaurar un régimen corporativo militar. Intentos que como sabemos fracasaron. 


\section{Notas}

${ }^{1}$ Edwards, Alberto, La Fronda Aristocrática. 5a.ed. Santiago: Del Pacífico, 1939

${ }^{2}$ Góngora Mario. Ensayo histórico sobre la noción del Estado en Chile en los siglos XIX y XX - Santiago: Universitaria, 1990

${ }^{3}$ Palacios, Nicolás. Raza Chilena- $2^{a}$. ed: Santiago: (s.n) 2v.,1918

${ }^{4}$ Nes El, Moshé. Inmigración y colonización en Chile - 1880/1920. Memoria para obtener el título de Ph.D.

${ }^{5}$ Segal Marcelo. Desarrollo del capitalismo en Chile: cinco ensayos dialécticos Santiago: [s.n.], c1953.

Vial Gonzalo. Historia de Chile. Santiago: Zig Zag, 2001

Jobet Julio. Los precursores del pensamiento social de Chile. Santiago: Universitaria, 1955-1956. 2 v.

Watto Stewart, W. Meiggs, Henry. Un pionero yanqui, Santiago (s.n.),1964

Nes El Moshé. Inmigración y colonización en Chile - 1880/1920. Op.Cit

${ }^{6}$ Donoso Ricardo. Alessandri, Demagogo y agitador. México Buenos Aires, Fondo de Cultura Económica, 1952.

Pinto Lagarrigue. Crónica política del siglo XX. Santiago, Orbe, 1970.

${ }^{7}$ Rotashnik, Michael. Nacism National in Chile - 1932/1938. Tesis Doctoral University, California, 1974.

El Mercurio. 18/4/1923

Las Últimas Noticias. 4/1/1923

${ }^{8}$ Barros Ortiz, Tobías. Recogiendo los pasos. Memorias. Santiago de Chile, Planeta.2 V-,1984.

Nes El, Moshé. Memorias del embajador chileno en Alemania, Tobías Barros Ortiz, durante la época de la Segunda Guerra Mundial y el Holocausto. En Judaica latinoamericana, Vol. 4, Ed. AMILAT y Ed. MAGNES de la Univ. Hebrea de Jerusalem. Jerusalem. 2001

${ }^{9}$ Diario El Trabajo. Órgano del Movimiento Nacional Socialista de Chile. 1935

${ }^{10}$ Nes El Moshé. Estudios sobre el Judaísmo Chileno (s.l.): Revista de Oriente y Occidente, 2010.

${ }^{11}$ Wurth Rojas Ernesto. Ibáñez, Caudillo Enigmático. Santiago, Pacífico, 1958. 377 p.

Nes El, Moshé. Marcos Chamudes Reitich, El Judaísmo Latinoamericano. Vól. VI, Pág. 229/249 
12 Boizard, Ricardo. Historia de una derrota. Santiago: Orbe, 1941.

Tobías Barros Ortiz. Op.Cit.

Michael Rotashnik. Op.Cit.

${ }^{13}$ Nes El. Moshé. Estudio sobre el Judaísmo Chileno, 2009, Jerusalem. La actitud de Chile frente a la inmigración judía durante la Segunda Guerra Mundial. Pág. 51/66. Rev. De Oriente y Occidente "Marcos Chamudes Reitich. De parlamentario Comunista a periodista anticomunista”. pág.229/248. Judaica Latinoamericana, Vól. VI, Ed. Amilat, Imp. Magnes de la Universidad Hebrea de Jerusalem

${ }^{14}$ Op. Cit. Estudio sobre el Judaísmo Chileno

Diario El Mercurio. Santiago. 25 de Mayo de 1940.

Diario La Hora. Santiago. 16 de Noviembre de 1938

El Diario llustrado. Santiago. 15 de Mayo de 1940

${ }^{15}$ Olavarria Bravo Arturo. Chile entre dos Alessandri: memorias políticas. Santiago, Nascimento, 19621965.

${ }^{16}$ Olavarría Bravo, Arturo. Chile entre dos Alessandri. Op.Cit.

Bragassi Hurtado, Juan. Cóndores, Achas y Estanqueros. El Nacionalismo Chileno entre 1945 y 1953.

Fuente: Pág. Web. Alerta Austral

Bilbao Vilches, Walter. Síntesis de la Historia del Nacionalismo en Chile: 1924-2003. Fuente: vans.mforos.com

La Historia de la Vanguardia Popular Socialista. Fuente: Pág. Web centroestudios.cl

${ }^{17}$ Fuente: Wikipedia, "Ariosto Herrera"

${ }^{18}$ Fuente: Wikipedia, "Ariostazo"

${ }^{19}$ Walter Bilbao Vilches. Síntesis de la Historia del Nacionalismo en Chile. Op.Cit.

20 Jordi Fuentes y Lía Cortés. Diccionario Político de Chile. Santiago. Ed. Orbe, 1967.

${ }^{21}$ Fuente: Wikipedia, "Partido Agrario Laborista"

${ }^{22}$ Marcos Chamudes. Cuidado no me desmienta. Editorial P.E.C., Santiago, 1945.

${ }^{23} \mathrm{Nes}$ El, Moshé. Estudio sobre el Judaísmo chileno. Guivataim, 2009, p. 99. 
${ }^{24}$ Nes El, Moshé. Estudio Sobre el Judaísmo Chileno. Op. Cit.

${ }^{25}$ Nes El, Moshé. Estudio sobre el Judaísmo Chileno. Op.Cit: Diario La Prensa: El gobierno lamenta un ataque a familias árabes. La Nación: El gobierno rechaza expresión contra colonia árabe. El Mercurio: Rechazada ofensa a árabes. Todos esos artículos fueron publicados en Santiago el 2 de Junio de 1971. La Prensa, Santiago, el 3 de Junio de 1971 publicó un extenso artículo sobre el asunto, principalmente las dos crónicas: Fuentes injurias a Colonia Árabe, y la otra, más extensa, citaba la intervención en el Senado, del Senador demócrata Cristiano, Fuentealba. La Tribuna de Santiago, órgano del Partido Nacional, publicó el 3 de Junio de 1971, en primera plana, en toda su extensión, una crónica con el título: Repudio a persecución racista de la Unidad Popular contra la colonia árabe y tienen crítica velada o no, sobre la importancia del elemento judío en los partidos de Unidad Popular.

${ }^{26}$ El nombre de esa Institución fue el de Dirección de Inteligencia Nacional (DINA)

${ }^{27}$ El Mercurio. Sección reportajes, 8/03/09. Un interesante estudio sobre Miguel Serrano lo realizó el profesor Gustavo Guzmán Castro, del Centro de Estudios Judaicos de la Universidad de Chile, que disertó en el Congreso Mundial de LAJSA, (Latinoamerican Jewish Studies), realizado en Tel Aviv en el año 2009, sobre el tema: "Judeofobia en Chile durante la Dictadura: el caso de Miguel Serrano".

${ }^{28}$ Anajnu. Boletín Nro 59 del 10/06/10. El artículo comenta "De manera que este grupo nazi, dulces palomas democráticas, solo se oponen a Israel, lo que para el Tribunal Constitucional de Chile no tiene importancia alguna"

${ }^{29}$ Caro, Isaac. Extremismo de Derecha y Movimientos - Santiago de Chile - L.O.M., 2007.

${ }^{30}$ Barros Ortiz Tobías. Recogiendo los pasos - Memorias. Santiago, Planeta y Espejo de Chile. 2 v. 1984 - 1988.

${ }^{31}$ Farías Víctor. Los nazis en Chile. Santiago, Seix Barral, 2003. v.2

${ }^{32}$ Diario Trabajo del 22 de Junio de 1935.

${ }^{33}$ Bowers Claude. Misión en Chile. Santiago, Del Pacífico

${ }^{34}$ Nes El Moshé. Estudio sobre el Judaísmo Chileno. Jerusalem, Rev. De Oriente y Occidente, 2010 


\section{Bibliografía}

BARROS Ortiz, Tobías. Recogiendo los pasos: memorias. Santiago de Chile: Planeta. 2 V, 1984.

BILBAO Vilches, Walter. Síntesis de la Historia del Nacionalismo en Chile.1924-2003. Fuente: vans.mforos.com

BOIZARD, Ricardo. Historia de una derrota. Santiago: Orbe, 1941.

BOWERS Claude. Misión en Chile. Santiago: Del Pacífico

BRAGASSI Hurtado, Juan. Cóndores, Achas y Estanqueros. El Nacionalismo Chileno entre 1945 y 1953.

Fuente: Pág. Web. Alerta Austral

CARO, Isaac. Extremismo de Derecha y Movimientos. Santiago, Lom, 2007.

DONOSO Ricardo. Alessandri, Demagogo y agitador. México Buenos Aires. Fondo de Cultura Económica, 1952.

EDWARDS, Alberto. La Fronda Aristocrática. 5a.ed. Santiago: Del Pacífico - 1939

El Ilustrado. Santiago, 15 de Mayo de 1940

El Mercurio. Santiago, 25 de Mayo de 1940

El Mercurio. Santiago, 18 de abril de 1923

El Trabajo. Órgano del Movimiento Nacional Socialista de Chile - 1935

FARÍAS, Víctor. Los nazis en Chile. Santiago: Seix Barral., 2003. v.2

Fuente: Wikipedia - "Ariostazo"

Fuente: Wikipedia - "Partido Agrario Laborista"

Fuente: Wikepedia - Ariosto Herrera"

FUENTES, Jordi y Lía Cortés. Diccionario Político de Chile. Santiago, Orbe, 1967.

GÓNGORA, Mario. Ensayo histórico sobre la noción del Estado en Chile en los siglos XIX y XX. Santiago, La Ciudad, 1981.

JOBET, Julio. Los precursores del pensamiento social de Chile. Santiago, Universitaria, 1955-1956. 2 v.

"La Historia de la Vanguardia Popular Socialista". Fuente: http://www.centroestudios.cl 
La Hora. Santiago, 16 de Noviembre de 1938

Las Últimas Noticias. 4/1/1923

NES EL, Moshe. "Memorias del embajador chileno en Alemania, Tobías Barros Ortiz, durante la época de la Segunda Guerra Mundial y el Holocausto". EN: Judaica latinoamericana. AMILAT - MAGNES, v.4, 2001.

NES EL, Moshe. "Marcos Chamudes Reitich". EN: El Judaísmo Latinoamericano. Vól. VI, p. 229/249

NES EL Moshe. “Estudio sobre el Judaísmo Chileno”. EN: Rev. De Oriente y Occidente, 2010.

NES EL, Moshe. Estudio sobre el Judaísmo Chileno. 2009 - Jerusalem-

NES EL, Moshe. Inmigración y colonización en Chile: 1880/1920. Memoria para obtener el título de Ph.D.

OLAVARRIA, Arturo. "Chile entre dos Alessandri: memorias políticas". Nascimento, 1962-1965. 4 v. pág.229/248. EN: Judaica Latinoamericana . Jerusalem: Amilat - Magnes. V.4

PALACIOS, Nicolás. Raza Chilena. 2 2a. Ed. Santiago. (s.n) 2v., 1918

PINTO Lagarrigue, Fernando. Crónica política del siglo XX. Santiago, Orbe,1970

ROTASHNIK, Michael. Nacism National in Chile 1932/1938 Tesis Doctoral University of California.1974

SEGA, Marcelo. Desarrollo del capitalismo en Chile: cinco ensayos dialécticos. Santiago [s.n.], c1953.

VIAL, Gonzalo. Historia de Chile. Santiago, Zig Zag, 2001.

WATTO, Stewart, W. Meiggs, Henry. Un pionero yanqui. Santiago (s.n.), 1964

WURTH Rojas, Ernesto. Ibáñez, Caudillo Enigmático. Santiago: Pacífico, 1958. 377 p 